\title{
Managing Sustainable Hybrid Organisations: A Case Study in the Agricultural Sector
}

\author{
Jennifer E. Díaz-Correa and Miguel A. López-Navarro * \\ Department of Business Administration and Marketing, Universitat Jaume I, 12071 Castelló de la Plana, Spain; \\ al336477@uji.es \\ * Correspondence: mlopez@emp.uji.es; Tel.: +34-964-387113
}

Received: 23 July 2018; Accepted: 22 August 2018; Published: 24 August 2018

\begin{abstract}
Research in the field of sustainability has been dominated by an instrumental logic in which social and environmental aspects are reduced to their ability to generate financial benefits. However, the increasing problems facing society are highlighting the need to change this logic. In this context, a growing body of literature is developing around what are known as hybrid organisations, entities characterised by their combination of a social and/or environmental mission with the pursuit of economic benefit. This research uses a descriptive case study approach in order to examine how a Spanish winery-Celler la Muntanya-has implemented a sustainable business model to create positive social and environmental change. The agricultural sector is receiving increasing attention in the sustainability field because of its impact on society and the territory. In addition, agricultural activity generates tensions between social/environmental dimensions-such as the preservation of ecosystems and biodiversity-and economic benefits. Our case study draws on the 'sustainability-driven hybrid business model' and its three basic elements: social and environmental change as organizational objective; mutually beneficial relationships with stakeholders; and progressive interaction with markets, competitors and industry institutions. Our findings contribute to the literature by helping to explain how agricultural organisations can implement their business model based on sustainability criteria.
\end{abstract}

Keywords: sustainability; hybrid organisations; sustainable business models; stakeholders; institutional entrepreneurship; agriculture; wine industry; smallholding; social and environmental change

\section{Introduction}

Over the last two decades, corporate sustainability has emerged as a line of inquiry of great relevance in the field of management [1,2]. Research in this field has traditionally adopted a perspective focused on organisation and value creation, with an approach clearly biased towards economic aspects, thereby reducing the consideration of social and environmental factors to their ability to generate financial benefits [3-7].

Authors such as Markman and Krause [8] affirm the need for a paradigm shift, referring to transition from a 'do-no-harm' approach to a more proactive 'do-good' philosophy that will regenerate and improve the natural environment. These authors claim that to be sustainable, any corporate activity must prioritise a model that places the environment first, then society, and thirdly the economy. Montalbon et al. [9] propose a similar logic, pointing out that in order to be sustainable, organisations must resist the tendency to balance the three aforementioned dimensions and, in trade-off situations, they must learn to prioritise environment, society and economy, in that order. In fact, maintaining the instrumental logic of the current triple bottom line approach has only limited the progress towards true sustainability [10]. 
In this context, many scholars have called for new business models and for further research to better understand how to manage businesses efficiently under sustainability principles [11-14]. The pursuit of social and environmental improvements through their practices, products and services, in parallel with good economic performance, is precisely what defines hybrid organisations $[15,16]$. Characterised by their sustainable and innovative business models, these organisations have generated a growing body of literature in recent years [15-23].

Despite the increasing number of academic contributions, the question of how hybrid organisations' business models are implemented in real situations in different contexts requires further attention. Taking the hybrid organisation literature as our frame of reference, in this article we focus on the so-called sustainability-driven hybrid business model $[15,16,23]$. We chose this model because we agree with Stubbs [24] (p. 302) that "to date, it is the most comprehensive discussion of the characteristics of a sustainable hybrid business model in the literature". In selecting the sustainability-driven hybrid business model as the framework that will guide our research, we will focus on the three basic elements that define it $[15,23]$ : social and environmental change as organizational objective, mutually beneficial relationships with stakeholders and progressive interaction with markets, competitors and industry institutions.

In light of the above, the objective of this research is to analyse how organisations can implement a sustainability-driven hybrid business model to create positive social and environmental change, by successfully managing the three aforementioned basic elements that define these models. For this purpose we carried out a descriptive case study of a Spanish winery-Celler la Muntanya. We focus on a specific industry - the agriculture sector-whose role in sustainable development is attracting increasing attention because of its impact on society and the territory [25-28]. In addition, agricultural activity generates tensions between social/environmental dimensions-such as the preservation of ecosystems and biodiversity-and economic benefits. The findings of our research contribute to the literature by helping to explain how agricultural organisations can implement their business model based on sustainability criteria as well as advancing understanding of the challenges facing hybrid organisations in that sector. These implications are important for academics and for practitioners.

The paper is structured as follows: we begin with a review of the literature on hybrid organisations, specifically the sustainability-driven hybrid business model. Section 3 describes the case study method used. The case study is then presented and we report our findings in relation to the actions of the company analysed with reference to the three aforementioned areas. Finally, the conclusions and limitations of the study are discussed.

\section{The Sustainability-Driven Hybrid Business Model}

The impacts of current human activities exceed the limits of our finite planet, giving rise to significant problems of sustainability [29-31]. There is a general consensus among researchers and practitioners that the challenges of sustainable development cannot be met without a parallel shift towards sustainability in organisations [14]. Indeed, the growth and success of most large enterprises is achieved by damaging or depleting the very resources they need, destroying forests or contaminating water, contributing to global climate change, and widening the gap between rich and poor [32].

Adopting changes in business models can undoubtedly contribute to the improvement of sustainable development framework objectives [33]. The prevailing logic underlying the business model has traditionally been of commercial value [34]; however, other institutional logics, including sustainability, can be combined with the commercial market rationale. Recent decades have witnessed the arrival of new business models that incorporate sustainability concerns $[12,33,35,36]$. The shift from conventional to sustainable business models must be made to accommodate increasingly relevant and pressing social and environmental dimensions [36]. Nevertheless, as these authors also point out, the key question is whether redefining business models to include such dimensions will bring about the transformational changes necessary to tackle the problems of sustainability that permeate our society, rather than simply tweaking the conventional commercial logic of the market. Drawing on 
the work of Markman et al. [37] (p. 673), such changes should not follow a triple bottom line (TBL) approach, which seeks to "minimize harm", as it may be insufficient, but should prioritise, in this order, environment, society and economics in order to "regenerate the environment and drive positive societal changes".

As Stubbs [24] points out, a stream of literature on sustainable business models has examined hybrid organisations [15-23]. These companies fall between for-profit and social and environmental organisations, which means they consciously align for-profit with non-profit practices, aiming to spread their innovative procedures in order to achieve sustainable objectives. However, although combining these two logics (social/environmental and market) in a shared space can lead to creative and innovative solutions, it is no less true that it can give rise to persistent conflicts and tensions that may even threaten their survival $[18,19,22]$. In this regard, agricultural activity has generated tensions between aspects such as preservation of ecosystems and biodiversity, food production, human welfare and economic benefits [26,27].

Taking the hybrid organisation literature as a reference, in this paper we focus on the sustainability-driven hybrid business model $[15,16,23]$. We discuss its main characteristics below.

\subsection{Social and Environmental Change as Organisational Objective}

Hybrid organisations define their mission around an environmental/social purpose. This mission embraces a future long-term mind-set for slower growth and more autonomous business progress, and is pursued by limiting profit distribution, reinvesting in the business and avoiding external financial control. Leadership is also a critical element in these businesses; they are generally run by ethical leaders, with a participatory or transformative style, who embody the social and environmental values underlying the mission and driving the organisation.

In this business model, firms focus on both reducing negative impacts and increasing positive ones simultaneously through their daily activities. While in traditional organisations, social and environmental issues are only considered if sufficient resources are available (there is a strong business case orientation), hybrid organisations configure their business model to address explicit social/environmental issues (the business case is secondary). Hybrid organisations challenge the trade-off between economic, social and environmental dimensions by developing business models that pursue synergies between them [16].

\subsection{Mutually Beneficial Relationships with Stakeholders}

This principle entails creating close, strong relationships based on trust by applying practices-such as employing local people, paying above market wages, training in sustainable techniques, creating a sense of family, satisfying the desire to live in a socially and environmentally responsible way, etc.- that improve life in the local community and environment. Appropriate management of stakeholder relations will have a direct influence on the success or failure of the entrepreneurial venture, especially for those who want to integrate sustainability principles into their business models [38]. If managers decide to establish sustainability as an essential value of the organisation, their relationship with stakeholders should be established on that principle. If the stakeholder-firm relationship is grounded on trust, emotion, conscience and mutuality, complexity is reduced, making the relationship closer and stronger [39].

\subsection{Progressive Interaction with Markets, Competitors and Industry Institutions}

While traditional firms seek to manipulate and dominate industry institutions to reduce standards and requirements in order to maintain their advantage over competitors, hybrid firms take the opposite path by drawing attention to their business model so that other companies imitate them for the good of society. In this way, sustainability-driven hybrid organisations act as institutional entrepreneurs [40,41].

In addition to harmonising economic viability and social/environmental mission, scalability is a major challenge for hybrid companies [21,24]. As mentioned above, these organisations tend 
to reject the assumption that the market needs unlimited economic growth in favour of creating a stable business and market, in an attempt to generate positive change while at the same time guaranteeing their future economic viability. However, this does not mean that hybrid organisations are not interested in growing. In fact, some growth is required to build a viable, stable and influential business. Crucially, hybrid organisations do not seek economic growth per se, based on the logic that this necessary economic growth is conditioned by the need to continue creating positive social and environmental changes. According to Haigh and Hoffman [15], when large scales are not feasible, the solution lies in trying to replicate the model to increase the population of small-scale hybrid organisations and, thus, increase their influence on the dominant large multinational companies.

\section{Material and Methods}

This research used a qualitative descriptive single case study approach. Qualitative research is particularly appropriate for analysing complex phenomena in areas where little prior knowledge is available [42]. Using a single case is a common method in qualitative research traditions [43]. Single case studies are used to analyse a case that, due to its significance, is considered valid enough to draw conclusions [44]. Such studies offer the possibility to analyse the phenomenon studied in depth when "how" and "why" questions are addressed [45]. This is our purpose in selecting a representative case study-a Spanish winery, Celler la Muntanya-to examine how a sustainability-driven hybrid business model is implemented in order to create positive social and environmental change. In a descriptive case study, researchers must previously define a theoretical framework to support the analysis of the phenomenon studied [46]. In this regard, and as we highlighted in the introduction section, we apply the sustainability-driven hybrid business model $[15,16,23]$ framework to guide our research and analysis of data. The analysed company was selected for its suitability to address the research topic in an environment-sensitive context; additionally, the firm's decision maker-the managing director-was willing to provide extensive data in supporting our research. Other relevant papers have applied qualitative research and descriptive single-case studies to explore similar topics in the hybrid organisations field $[23,47]$.

Data were collected from two sources in this study: documents (internal and external to the company) and personal in-depth interviews. The use of primary and secondary data improves our understanding of how the sustainable business model was implemented in the case selected, through multiple data collection strategies. The process began with a thorough analysis of the firm's website, and information in its social media-Facebook and Twitter. Press articles, interviews in the press, radio and television were also evaluated, as well as videos posted on several platforms. All this information was carefully analysed by the researchers. Additionally, two personal in-depth interviews were conducted with the company's managing director at the winery, lasting about two and two-and-a-half hours, respectively. The interviews were designed with the purpose of exploring in depth all the issues about which the documentary evidence did not offer enough information, as well as resolving doubts and controversies that these secondary sources had aroused in the researchers. The use of several sources of information (primary and secondary) allowed the researchers to triangulate the data, thereby improving the validity of the study. Reliability was ensured by establishing an initial protocol to deal with the documentation; although such protocols are imperative for multiple case studies, they are also recommended in single-case studies.

Celler la Muntanya (CLM) is a small winery founded in 2004 by two enterprising friends, Toni Boronat and Juan Cascant, a project that a new member later joined-Josep Marco. Although they had no connections with the agricultural industry, they share a philosophy of life based on a commitment to the ecosystem and the recovery of the territory's social and cultural values. The firm is located in Muro d'Alcoi (Alicante, Spain), an area that was largely given over to vineyards in the past. However, as agricultural practices changed, first towards olive production and then abandoned in favour of the textile industry, real estate and tourism, the vineyards practically disappeared. As Compés and Asensio [48] (p. 186) point out, this area is a good example of the problems of 
the Spanish Mediterranean rural environment: "small-scale farming, lack of profitability, rural exodus, disappearance of farms, abandonment of land, aging of farmers and lack of generational change [...] This strongly regressive agricultural and rural dynamics is a threat to the landscape, cultural heritage, native varieties and biodiversity linked to traditional agriculture".

The CLM project started as a dream, almost as a hobby, when firm's promoters made a cask of wine as a 'simple experiment' with the help of a book. When they decided to take the project further, they concluded that it would take too long if they planted new vineyards, so they came up with the idea of regenerating the old vineyards and local strains. They now mainly use grapes from old smallholdings, almost all of which were semi-abandoned or at risk of being abandoned due to their low profitability. These old vineyards of predominantly autochthonous varieties are what give the firm's wines their quality and singularity.

CLM produces wines with their own character, depending on the blend of local strains. The micro-vineyards characteristics vary considerably, which is what enables the firm to create such singular wines. The company's mission is to provide high-quality wines, and it produces between 40,000 and 50,000 bottles a year. Most of its wines have been rated 'excellent' by Spain's best known guide Peñín, with scores of between 90 and 95 points out of 100. In addition, as part of its philosophy of sustainability and proximity, the winery prioritises its sales activity in the local region (Valencian Community), although the success of its wines at international events has meant it is now exporting to other countries. Currently, its sales are distributed as follows: $30 \%$ export, $7 \%$ national, $49 \%$ Valencian Community, and $14 \%$ direct sales through the cellar.

The firm contends that smallholdings can be profitable, and that their regeneration favours the environment and wider society. CLM looks beyond the traditional concept of the smallholding, which has frequently been derided as unworkable and incapable of sustaining a family, and includes aspects such as environment, biodiversity, Mediterranean gastronomy and landscape in its definition. This approach is coherent with what Ferrás et al. [49] (p. 8) refer to in stating that "the concept of smallholding should be part of a new interpretive paradigm of the countryside and rural areas in which these are perceived not only as places to produce but also to live in harmony with the environment".

Under the 'Microvinya' (Micro-vineyard) project, the firm has signed agreements with owners who want to regenerate their smallholdings under the winery's guidance, and working within sustainable parameters to obtain the highest quality grapes. Prices are set according to the principles of social justice and quality. Juan Cascant, the managing director, prefers to describe his business as a collaborative rather than a cooperative management model, since high quality is a mandatory requirement for the grapes to be accepted. Through this collaborative model, the firm aims to ensure the smallholder makes a profit so the vineyards are not abandoned, and in turn, the ecosystem and biodiversity are preserved.

This philosophy led to the creation of a new label (Microvinya), which was registered by one of the partners, Juan Cascant. His aim in doing so was to spread the project's philosophy to other areas, enabling smallholders to establish collaborative links, even among competitors, to solve common problems and achieve common objectives. The literature has highlighted the importance of cooperation in the case of small and medium-sized enterprises in the agriculture sector [50-52]. CLM's owners regard the mission to share the essence of the project as an obligation, to promote similar projects and involve more people in other regions. Five conditions must be met before a wine producer can be granted the Microvinya label, namely, verification that:

1. The grape producer has received a fair price.

2. The grape has been produced according to good agricultural practices (GAP), from local strains, and with respect for the ecosystem.

3. The cellar is an active member of its local community, and it gives to and cooperates with its environment.

4. Its promotion activities are designed to take into account the local culture.

5. The cellar has active contact with local schools and/or universities and uses education as a driver of sustainable development in the territory. 
This project has close ties with movements such as the Economy for the Common Good (ECG) and Slow Food. The ECG [53] is a growing social movement that is gaining global recognition and plays an important role in the firm's philosophy: in an informal self-evaluation of ECG balance, CLM obtained 875 points out of a maximum 1000 [48]. Similar to ECG, the Microvinya project fosters an entrepreneurial model that puts people and the environment first. For this reason, Juan Cascant participates actively in the ECG movement by giving talks and seminars. The company is also a member of Slow Food València, whose seal of approval appears on its labels.

The firm follows what Juan Cascant calls a "proximity strategy", which entails making maximum use of local means and resources. As well as the grapes, local suppliers provide all the business's inputs whenever possible, such as boxes, pallets, labels, and so on.

\section{Results}

CLM's sustainability-driven hybrid business model can be described as follows.

\subsection{Social and Environmental Change as Organisational Objective}

Sensibility to their territory and the desire to improve the life of vineyard smallholders demonstrate that CLM is motivated by the objectives of social and environmental change. CLM was set up with the aim of developing a different kind of business project based on adapting to the environment, the conservation of local heritage, and a social commitment rather than maximising profits. CLM prioritises local development by paying growers a fair price, conserving the local ecosystem through good agricultural practices and preserving local strains, and promoting local culture. This philosophy is clearly evidenced in the firm's mission [54]: “To regenerate abandoned vineyards and restore and replant autochthonous vineyards; to pay producers a fair price for their work; to promote the business in coherence with the culture of the land where the grapes are grown and establish close links with education".

Although the winery partners' objective was to develop a business project that was not based on profit maximisation, where ethical commitment to the ecosystem comes before business profit, one of their goals is to secure what could be termed a 'fair' economic return. As the company's website states, "Celler la Muntanya's viticulture activity follows good agricultural practices (GAP), which are intrinsically linked to its target of four-fold profitability: economic, social, environmental and cultural" [54]. Juan Cascant also explicitly points out that the CLM's objective is "not to produce to sell, but to generate value". This concept of value, as Cascant highlights, must be understood in the broad sense of seeking harmony and balance between social, environmental, cultural and economic dimensions, generating a situation in which not only those involved in the value chain, but also the environment and society as a whole are winners. It is, in short, a paradigm based on collaboration and production to add value to society.

In addition, as Haigh and Hoffman [15] (p. 128) point out, leadership "is critical to the development and operation of a hybrid's mission". Juan Cascant can be classified as an entrepreneurial leader driven by strong social and environmental values that have guided the CLM's mission. Furthermore, as we will discuss in the next section, he has taken a proactive approach in managing the firm's relationships with its stakeholders in line with the principles of sustainability.

\subsection{Mutually Beneficial Relationships with Stakeholders}

The management of stakeholder relationships is another element that differentiates hybrid organisations from traditional ones [15,23]. In this section we focus on three key stakeholders that, in the case of the company analysed, contribute decisively to the configuration of its business model: smallholders-grape suppliers, distributors/customers and the local community. 


\subsubsection{Smallholders}

Smallholdings, as previously highlighted, are the cornerstone of the project. What differentiates CLM is the collaborative management model it has established with grape producers. According to the company's website, "the company currently works with more than 25 smallholders producing traditional grapes, from vines aged between 5 and 80 years old" [54]; the average size of the smallholdings is about 6000 square meters. Four secondary schools also supply grapes through the Microvinya project, although their participation is related more to the firm's educational objective to symbolically recuperate the presence of the vineyard in the area, rather than as suppliers.

CLM has established two types of smallholder agreement for grape suppliers: (a) those who do not want to work on their own land but are willing to rent it out; in this case CLM provides the personnel to cultivate these smallholdings; and (b) those who want to work in their own small fields, and sell the grapes to the winery; in this case the owners sign a contract with the winery, undertaking to cultivate according to the quality parameters established by the firm in return for a fair payment (in cash or in kind) for their work. In addition, a small number of smallholders, (currently three), who despite entrusting the care of the vineyards and winemaking to CLM, plan to market the wine under their own label.

Because fair prices are established, CLM pays more for the grapes than other wineries, on average about 0.55 euro $/ \mathrm{kg}$, which is practically four times the price paid by the large wineries operating in the surrounding areas. The payment system is also unusual in that when a wine is officially recognised or gains in reputation, and consequently its price rises, this increase is passed on to the smallholder, thus upholding the firm's fair trade policy.

Many of the smallholders appear to share the same dream as CLM's entrepreneurs: to regenerate their territory and return to their origins, although the fair price or the desire to produce their own wine are also factors that have led them to join the project. The following statements from two micro-vineyard owners-the first, Juan Fuster, a professor in quantum physics who wanted to have his own wine made with grapes from his land; the second, Beatriz Vicent, a local architect with the same aspiration who also wanted to sell her wine under her own label—show how they share the philosophy of the CLM project:

It is a wine that is produced with affection; it has my sun and my soil. It has all the values of our environment and all the work that we have done with our own hands, mine and those of my family. We do not pursue quantity, but quality, [we want it] to have the flavour of here, to describe our mountains and, above all, to transmit all the love that we have put into it (Juan Fuster). [55]

This isn't going to feed us. But it's something more romantic. It's about restoring the value of this land that was abandoned (Beatriz Vicent). [56]

These testimonials seem to confirm that the emotional bond with the land goes beyond any interest in a fair payment. For these smallholders, this project offers a way to maintain contact with their native land and the people with whom they grew up. They had lands that were abandoned, but that they were able to recover and work with their respective families. In these cases, the micro-vineyard growers have neither the knowledge nor the means to set up a winery, only the passion for the wine and their territory. Their wine is produced by CLM, with grapes harvested from their land under Microvinya principles and CLM's technical guidance.

Additionally, CLM is currently developing an original initiative to allow other people to join the project, "Your own wine, with Micro-vineyard". To join this project individuals must have a micro-vineyard and the desire to produce their own wine. People from other places, in Spain or abroad, are invited to buy or rent small parcels of land in CLM's area of operations for their micro-vineyards. The project intends to apply the same agreements as with the local owners. 


\subsubsection{Distributors/Customers}

According to Juan Cascant, of all the issues involved in ethical smallholder production, the commercial area is the most complex. Distributing the wines in a way that is consistent with CLM's philosophy is not proving to be simple. CLM aims to attract distributors that share the same values and that want to add value for their customers and society. For the company, the ideal distributor is one that not only cares about the quality of the wine, but who will care about a valuable product and be able to spread the firm's philosophy correctly. The following testimonials from restaurants supplied by CLM reflect this attitude [57]:

A project like that of Celler La Muntanya is something we can relate to. It's a commitment to the future, but at the same time it's a return to our origins and the regeneration of an identity that we would probably have lost (Alberto Redrado, L'Escaleta-Restaurant, Cocentaina, Alicante).

When one hears about this project and such a romantic adventure that is the recovery of the smallholdings, and specifically the Microvinya project, one doesn't want to be left out; one wants to participate in this project. I think that the good has to be shared (José Luis G. Sirvent, El Sequé -Restaurant, Rural house hotel, El Pinós, Alicante).

The priority in our rural hotel is to spread our culture, our gastronomy, our environment, and for this reason, we buy Celler La Muntanya's wines, because the Microvinya project fits perfectly with our enterprise's philosophy (Raquel Soler, Casa Rural Bons Aires Hotel, Alcoi, Alicante).

As the company is aware that not all distributors will transmit its philosophy to customers in the right way, it prefers to use the shortest possible distribution channels. Having confirmed that conventional distribution channels did not provide adequate access to what the company considered to be its true customers, the decision was made to operate, as far as possible, through a more direct, proximate but more risky distribution system that would facilitate contact with the customer. This has come to fruition, mainly in the region (Valencian Community), where the company uses its own distribution channel to reach its customers, mainly restaurants and specialised shops. Distribution to the rest of the country or abroad is carried out by small-scale (not nationwide) distributors who have customers whose profile matches the type of products the winery offers, and through which the project is implicitly explained. The firm is therefore actively pursuing a distribution model that can understand and transmit its history and its project. CLM also invests a great deal of effort in attending to customers in person at the cellar, aiming to provide a unique experience and awaken the same passion that the firm's owners feel for the wine and the territory, thus enabling a kind of friendship to develop. CLM has established direct contact with consumers through its Ruta de Microvinya wine tour and the Vi i Amics [Wine and Friends] group.

On the Ruta de Microvinya wine tour, members of the public visit the cellar and some of the project's vineyards, learn more about the Microvinya project and the process of the winemaking, and taste and, if they wish, buy CLM's wines. This is another channel through which CLM directly shares and spreads its philosophy, values, business model and love for the territory, invites visitors to join $\mathrm{Vi} i$ Amics, and makes local sales. This wine tour has also helped other related local businesses to develop or expand, such as bird-watching activity, tourist accommodation and restaurants. In turn, Vi i Amics is a platform/group, managed mainly through Facebook, where people who value CLM's wines, the land and the winemaking process can meet. Members of this group promote and disseminate the brand and the firm's philosophy elsewhere by word of mouth, and receive discounts on the products they purchase. In its direct dealings with consumers, CLM treats them in the same way as other stakeholders, as friends. The following sentence is taken from the CLM website [54]:

At Celler la Muntanya the grapes are supplied by friends, we manage the winery among friends, and now we need more friends to enjoy our wines. 
The company's intention is to sell as much as possible at the cellar door in order to meet their customers in person and transmit the firm's philosophy as they want it to be known. Juan Cascant recognises that selling wine through the cellar brings results more slowly, but by doing so he ensures he is reaching the right people. When the perception of the product's value shifts from the price to the concept, it is easier to reach more people.

\subsubsection{Local Community}

CLM follows two strategies in its contribution to the local community: education and culture (both are inherent to the principles of the Microvinya project). The firm has shown particular interest in establishing links with the universities in the region. This is not only because through universities CLM can spread its philosophy and introduce its business model and the Microvinya project to younger people, but also because universities can contribute on a technical level to its work in recovering extinct strains in line with the firm's mission. Specifically, CLM has links with the University of Valencia, the University of Alicante, the Polytechnic University of Valencia, and the Miguel Hernández University of Elche (Alicante). All these universities support the Microvinya project through research initiatives linked to the project and also through courses. The Miguel Hernandez University and CLM have also recently formalised the creation of a university chair entitled Càtedra Celler de la Muntanya, Territori i Patrimoni Vegetal, the objectives of which include training, research, and the development and transfer of knowledge in different fields related to the cultivation of traditional vine varieties in south-east Spain. In addition, it seeks to promote the rural business ecosystem and the way it shapes the landscape and favours a qualitative development model through training activities, research, and by organising seminars, conferences and other outreach activities.

As mentioned above, CLM has close links with four secondary schools where experimental vineyards have been established. The aim of these micro-vineyards is didactic: students see the vine growing and participate in the harvest and in making the wine. In these experimental vineyards, students learn about local crops, wine, love for their local culture, the philosophy of respect for the land and people, as well as being introduced to a potential way of life and employment.

CLM also combines its commitment to education with the dissemination of its philosophy by organising courses and conferences on the subject of Microvinya and smallholdings. To date, the firm has organised two conferences on smallholdings (El minifundio como defensa del ecosistema mediterráneo [The smallholding as a defence of the Mediterranean ecosystem]) and four micro-vineyard courses (Curso de Microviñas, una herramienta para el desarrollo rural [The micro-vineyard, a tool for rural development]). The aim of these courses is to analyse how to bring education and knowledge to rural communities and smallholdings, and to provide them with the tools, adapted to their reality, to turn their weaknesses into strengths and threats into opportunities.

The company's second local community strategy, through its contribution to Valencian (local) culture, involves several activities. The CLM project has attempted to engage and has the support of a broad group of people from different aspects of the region's cultural and social life (painting, poetry, music, gastronomy, etc.). In this context, Elviart (the art of wine) has been created as an association, providing a space for other agents as well as CLM, to promote cultural and artistic activities related to the world of wine, through which various events have been organised over the past years. Several of these events linking culture-poetry, music and painting exhibitions by local artists-and wine are held periodically in the cellar, the vineyards or in Casa Alonso, an iconic country house considered to be part of the local cultural heritage and a symbol of the wine sector's importance in the twentieth century in Muro d'Alcoi [58], which has been renovated and is now the headquarters of the Microvinya project. In this way, wine becomes the linchpin for a cultural project with close ties to the territory. Another illustration of the cellar's links with the local culture is its wine labels, which are in Valencian (the local language) and reproduce short poems written by local poets. Valencian is also the main language used in the cellar's social media. 


\subsection{Progressive Interaction with Markets, Competitors and Industry Institutions}

As Haigh and Hoffman [15] point out, hybrid organisations pursue the approval of their business model by the industry institutions and markets in which they operate, as well as encouraging other firms to emulate the model for the good of society and to foster changes in it. On the first of these issues, Juan Cascant has proactively sought direct relationships for CLM with public institutions such as the Generalitat Valenciana [the regional government] to obtain support for small firms with sustainable business models guided by ECG, and also for the Microvinya project. Additionally, CLM continues to promote its business model and values through agreements with universities and schools and by organising conferences and courses. Through such activities, alliances are forged with individuals who in turn, help convince others, thus strengthening the CLM business model and the Microvinya project. In the long term, this could potentially influence institutional leaders and politicians to change the regulations and industry standards in favour of businesses run on this model. Interest has also been expressed from universities in other regions and countries, the University of the Basque Country and Harvard University among others, which have invited Juan Cascant to talk about the CLM business model [59].

The second issue, concerning emulation, is directly related to scalability. According to Haigh and Hoffman [15] (p. 132), "if large scales are not possible, the question turns to one of replicating the model to grow the population of small-scale hybrid producers to increase their influence over dominant, vertically integrated, multi-national enterprises". When they created their business model, CLM's owners had limited company growth in mind, as they did not want to produce more than necessary and did not wish to expand beyond the firm's geographical area, a philosophy that they have managed to maintain; however, their expectation is that their business model can be applied elsewhere through the Microvinya label. The Microvinya project has drawn in new people by putting forward practical proposals that can be shared in other areas where there is concern for the environment and local communities. Ultimately, CLM seeks to inspire other companies to pursue sustainable farming practices and socially responsible policies.

Table 1 shows the main findings presented in this section. 
Table 1. Celler la Muntanya's (CLM) sustainability-driven hybrid business model

\begin{tabular}{|c|c|c|}
\hline $\begin{array}{l}\text { Social and Environmental Change as } \\
\text { Organisational Objective }\end{array}$ & Mutually Beneficial Relationships with Stakeholders & $\begin{array}{l}\text { Progressive Interaction with Market and } \\
\text { Industry Institutions }\end{array}$ \\
\hline $\begin{array}{l}\text {-CLM's mission focuses on social and } \\
\text { environmental issues: "Regenerate abandoned } \\
\text { vineyards and restore and replant autochthonous } \\
\text { vineyards; pay producers a fair price for their work; } \\
\text { promote the business in coherence with the culture } \\
\text { of the land where the grapes are grown and } \\
\text { establish close links with education". } \\
\text {-Paradigm shift from "produce to sell" to "produce } \\
\text { to generate value for society". } \\
\text { - Harmonisation of quadruple profitability: social, } \\
\text { environmental, cultural and economic. } \\
\text { - Links with Slow Food and Economy for the } \\
\text { Common Good (ECG) movements. }\end{array}$ & $\begin{array}{l}\text { Smallholders } \\
\text {-Fair prices are set. } \\
\text { - Technical support. } \\
\text { Distributors/customers } \\
\text {-CLM tries to attract distributors that share its values and that can } \\
\text { successfully spread its philosophy. } \\
\text { - The firm prefers more direct distribution channels and attending customers } \\
\text { in person at the cellar (dealing with consumers directly). } \\
\text { Local community } \\
\text { Education ('driver of change'): } \\
\text {-Agreements with universities for the development of research activities } \\
\text { related to viticulture as well as courses. } \\
\text {-Didactic micro-vineyards in secondary schools. } \\
\text { - Organisation of courses and conferences to disseminate smallholder culture } \\
\text { and the Microvinya project philosophy. } \\
\text { Culture: } \\
\text {-Links with people related to the cultural and social life of the region and } \\
\text { organisation of events in various fields: poetry, music, painting, etc. } \\
\text { Other stakeholders } \\
\text { Proximity strategy-maximum use of local resources. Whenever possible, } \\
\text { local suppliers provide all products such as boxes, pallets, labels, etc. }\end{array}$ & $\begin{array}{l}\text {-Extensive promotion of change through } \\
\text { agreements with universities. } \\
\text { - Relationships with public institutions in order } \\
\text { to obtain support for new and more sustainable } \\
\text { business models as an alternative to the } \\
\text { dominant industrial agriculture model. } \\
\text { The company acts as an } \\
\text { institutional entrepreneur. } \\
\text { - Through the Microvinya project, and the } \\
\text { associated label, the company encourages other } \\
\text { companies in geographical areas with similar } \\
\text { structural characteristics to emulate its business } \\
\text { model in order to contribute to the good } \\
\text { of society. }\end{array}$ \\
\hline
\end{tabular}




\section{Discussion and Conclusions}

This research used a descriptive case study approach to examine how a Spanish winery, Celler la Muntanya, has implemented a sustainable business model to create positive social and environmental change. Focusing on the agriculture sector is a useful approach due to the considerable impact agricultural practices have on sustainability. The sustainability-driven hybrid business model $[15,16,23]$ framework guided our research and analysis of data.

The company analysed is a revealing case of an innovative hybrid company that reflects a real change in the conception of what it means to be sustainable, from the current mainstream focus on being a 'less unsustainable' company (sustainability enacted as reducing firms' negative impact on the environment and their communities) to becoming a 'more sustainable' organisation (sustainability enacted as reducing negative and creating positive impacts) [16,60]; or, similarly, what authors such as Markman and Krause [8] refer to as a transition from a 'do-no-harm' approach to a more proactive 'do-good' philosophy to regenerate and improve the natural environment. In fact, the firm's mission combines elements such as preservation of the ecosystem, fair remuneration for the producer, and development of agricultural activity by establishing strong links with local culture and education. All these policies are oriented towards the creation of positive social and environmental change.

The company's philosophy is grounded on a collaborative model - the firm has established strong connections with collaborative movements such as Slow Food [61] and the Economy for the Common Good [53]—and a paradigm shift: from "produce to sell" to "produce to generate value for society". The concept of value is interpreted in a broad sense, seeking harmony and the right balance between the social, environmental, cultural and economic dimensions, which shapes the purpose of the company's business model. This approach is consistent with the essence of hybrid organisations, which challenge the notion of trade-offs between the economic, social and environmental dimensions by developing business models that pursue synergies between them [16]. Furthermore, CLM has proactively followed a sustainable model since the beginning of its operations. Unlike many companies, the firm did not wait for societal pressure to change to sustainable practices; rather, from the outset it prioritised the conservation of a threatened local agricultural ecosystem that represents an alternative to the dominant agricultural model, and embraced an ethical vision to work with and for people. The need to change the dominant agricultural model has been underlined in several studies [25,27,61].

CLM's business model is also characterised by its efforts to develop reciprocally beneficial relationships with its stakeholders, based on proximity and trust. The company actively avoids over-production of its wines, since its aim is to maintain close relationships with its stakeholders and trade fairly with the smallholders located in the winery's area of influence. By using smallholdings, a common, longstanding yet undervalued agricultural practice in this region, CLM's project helps to preserve the agricultural ecosystem. The firm sees the smallholding not just as a small parcel of land, but also as a place that brings together tradition, culture, identity, landscape preservation and regeneration of the territory. This combination unifies and interrelates a range of stakeholders to achieve this objective, namely, to produce in order to generate value for the local community.

At a more specific level, our findings have identified the intensity of the relationships with three groups of stakeholders: (a) smallholders-a collaborative management model based on technical support and a fair payment system; (b) distributors-the firm prioritises those that are able to transmit the company's values and philosophy through the distribution channel; and c) the local community-through education and culture. The company considers education to be a real "driver of change", and has established agreements with local universities and designed micro-vineyards as an educational strategy with secondary schools. The company also promotes local culture through its project to bring together a wide range of people from the world of culture around the world of wine, by organising poetry, music, painting and other cultural events.

Furthermore, CLM's vision of its stakeholders goes beyond the conventional approach. Haigh and Hoffman [16] (p. 233) point out that "hybrids enact a broader definition of stakeholders that includes traditional stakeholders [... ] and 'fringe' non-human stakeholders, such as ecological and biophysical 
phenomena". This is the case of CLM where, following authors such as Starik [62], Driscoll and Starik [63] or Haigh and Griffiths [64], the natural environment is considered to be a key stakeholder that determines the essence of the organisation.

CLM's proximity strategy to attract and relate with stakeholders also helps to create stronger connections and develop a spirit of trust and collaboration and, therefore, build the social capital essential to achieve the desired common good [65]. The participative and transformative leader role undertaken by Juan Cascant-the firm's general director and the main promoter of the project-is also noteworthy. He has remained loyal to his personal values throughout the whole process, and has successfully transmitted these values to the firm's stakeholders by developing trusting and collaborative relationships with them. These findings are consistent with the literature, which has emphasised the importance of the values of the entrepreneur and his/her leadership style in sustainable entrepreneurship [66-68] and hybrid organisation [15,16,23,69] fields.

Finally, and in accordance with what constitutes a sustainability-driven hybrid business model, CLM seeks to legitimise and promote its business model through the institutions and markets in which it works, while at the same time encouraging other companies to emulate its model in order to contribute to the good of society. Sustainable institutional entrepreneurs engage with societal change through changing market conditions and government policies [40,41]. In this sense, CLM has sought to raise awareness to legitimise its business model and foster social change. To this end, the company uses education in its broadest sense (agreements with universities and schools, courses and conferences, etc.), as well as seeking the support and commitment of political institutions with the capacity to intervene in social change, to promote and develop a business model in the most human agricultural context as an alternative to the dominant industrial agriculture model. This commitment to awareness-building, education and institutional pressure has also been identified in other studies focused on companies with sustainable business models, such as the B Corps [24].

Regarding the scalability of its business model, the company does not aim to expand its productive activity beyond the region in which it is presently established. However, its strategy is replicated in the Microvinya project, and the associated label, through which it encourages other firms to emulate its business model in other geographical areas with similar structural characteristics [15]. This enables collaborative links to be established between producers, even between competitors, from other territories in order to solve common problems and achieve common objectives. The development of projects of this nature can constitute a force for change at the social and environmental level.

In summary, the features of the CLM model reinforce the characteristics of the sustainability-driven hybrid business model in the areas of embracing social and environmental change as organizational objective, developing mutually beneficial relationships with stakeholders and interacting progressively with markets and institutions. Furthermore, it provides valuable examples of how a firm has implemented a sustainability-driven business model in a specific industry, namely the agricultural sector. We refer to the agricultural sector throughout the paper, because although this is a very diverse and complex sector, we believe that the study's findings can be applied in other agricultural contexts beyond the wine industry, in pursuit of alternatives to the dominant agricultural model.

CLM is a small firm that has been shaping its sustainable business model since its beginnings, based on the values of its promoters, especially its managing director. At this point, it is important to consider to what extent new business projects may be set up on the basis of a business model with similar characteristics, or to what extent other firms can make the transition from traditional business models to models such as the one addressed in this research. The processes of transition towards a sustainability-driven hybrid business model seem more likely in the case of small firms, which face lower stakeholder pressure [70]. As Shevchenko et al. [71] (p. 925] suggest, "for small innovative firms, the decision to engage in such a change largely depends on their readiness to change, an internal factor, and not their ability to offset stakeholder pressure"; this readiness to change can be largely conditioned, as in our study, by the role of entrepreneurial leaders driven by their sustainability principles and 
personal values [38]. However, if these sustainable hybrid business models are not adopted widely by bigger companies, serious doubts can be raised about their true transformative impact [24].

Although the results of our research are encouraging, they are tempered by its limitations. Our study focused on sustainability-driven hybrid models in the specific case of a Spanish winery, and is therefore limited by contextual factors, namely, industry and geography. Nonetheless, the results of our research support theoretical principles that go beyond the case analysed and can potentially be transferred to other similar situations [45]. It should be noted that a single-case study reduces the opportunity to use Yin's replication logic, as compared to the multiple-case study. Another limitation of the study lies in having focused on the in-depth interviews on the company's CEO, without carrying out further interviews with other stakeholders, whose opinions were essentially extracted from secondary information sources.

Author Contributions: Conceptualization, J.E.D.-C. and M.A.L.-N; Methodology, J.E.D.-C. and M.A.L.-N.; Investigation, J.E.D.-C. and M.A.L.-N.; Writing-Original Draft Preparation, Review \& Editing, J.E.D.-C. and M.A.L.-N. Both authors read and approved the final manuscript.

Funding: This research received no external funding.

Acknowledgments: The authors would like to thank the editor and the reviewers for their useful and insightful comments and suggestions.

Conflicts of Interest: The authors declare no conflict of interest.

\section{References}

1. Starik, M.; Turcotte, M.F. With a little (urgent) help from our friends: Management academic leadership for a sustainable future. Organ. Environ. 2014, 27, 3-9. [CrossRef]

2. Hahn, T.; Figge, F.; Aragón-Correa, J.A.; Sharma, S. Advancing research on corporate sustainability: Off to pastures new or back to the roots? Bus. Soc. 2017, 56, 155-185. [CrossRef]

3. Walsh, J.; Weber, K.; Margolis, J. Social issues and management: Our lost cause found. J. Manag. 2003, 29, 859-881.

4. Kallio, T.; Nordberg, P. The evolution of organizations and natural environment discourse. Some critical remarks. Organ. Environ. 2006, 19, 439-457. [CrossRef]

5. Banerjee, S.B. Embedding sustainability across the organization: A critical perspective. Acad Manag. Learn Educ. 2011, 10, 719-731. [CrossRef]

6. Tregidga, H.; Kearins, K.; Milne, M. The politics of knowing "organizational sustainable development. Organ. Environ. 2013, 26, 102-129. [CrossRef]

7. Tregidga, H.; Milne, M.J.; Kearins, K. Ramping up resistance: Corporate sustainable development and academic research. Bus. Soc. 2018, 57, 292-334. [CrossRef]

8. Markman, G.D.; Krause, D. Theory building surrounding sustainable supply chain management: Assessing what we know, exploring where to go. J. Supply Chain Manag. 2016, 52, 3-10. [CrossRef]

9. Montabon, F.; Pagell, M.; Wu, Z. Making sustainability sustainable. J. Supply Chain Manag. 2016, 52, 11-27. [CrossRef]

10. Gao, J.; Bansal, P. Instrumental and integrative logics in business sustainability. J. Bus. Ethics 2013, 112, 241-255. [CrossRef]

11. Boons, F.; Lüdeke-Freund, F. Business models for sustainable innovation: State-of-the-art and steps towards a research agenda. J. Clean. Prod. 2013, 45, 9-19. [CrossRef]

12. Matos, S.; Silvestre, B.S. Managing stakeholder relations when developing sustainable business models: The case of the Brazilian energy sector. J. Clean. Prod. 2013, 45, 61-73. [CrossRef]

13. Hörisch, J.; Freeman, R.E.; Schaltegger, S. Applying stakeholder theory in sustainability management: Links, similarities, dissimilarities, and a conceptual framework. Organ. Environ. 2014, 27, 328-346. [CrossRef]

14. Schaltegger, S.; Hansen, E.G.; Lüdeke-Freund, F. Business models for sustainability: Origins, present research, and future avenues. Organ. Environ. 2016, 29, 3-10. [CrossRef]

15. Haigh, N.; Hoffman, A.J. Hybrid organizations: The next chapter of sustainable business. Organ. Dyn. 2012, 41, 126-134. [CrossRef] 
16. Haigh, N.; Hoffman, A.J. The new heretics: Hybrid organizations and the challenges they present to corporate sustainability. Organ. Environ. 2014, 27, 223-241. [CrossRef]

17. Battilana, J.; Dorado, S. Building sustainable hybrid organizations: The case of commercial microfinance organizations. Acad. Manag. J. 2010, 53, 1419-1440. [CrossRef]

18. Battilana, J.; Lee, M.; Walker, J.; Dorsey, C. In search of the hybrid ideal. Stanf. Soc. Innov. Rev. 2012, 10, 51-55.

19. Battilana, J.; Lee, M. Advancing research on hybrid organizing-Insights from the study of social enterprises. Acad. Manag. Ann. 2014, 8, 397-441. [CrossRef]

20. Santos, F.M.; Pache, A.-C.; Birkholz, C. Making hybrids work: Aligning business models and organizational design for social enterprises. Calif. Manag. Rev. 2015, 57, 36-58. [CrossRef]

21. Jabłoński, A. Scalability of sustainable business models in hybrid organizations. Sustainability 2016, 8, 194. [CrossRef]

22. Kannothra, C.G.; Manning, S.; Haigh, N. How hybrids manage growth and social-business tensions in global supply chains: The case of impact sourcing. J. Bus. Ethics 2018, 148, 271-290. [CrossRef]

23. Hoffman, A.J.; Badiane, K.K.; Haigh, N. Hybrid organizations as agents of positive social change: Bridging the for-profit \& non-profit divide. In Using a Positive Lens to Explore Social Change and Organizations: Building a Theoretical and Research Foundation; Golden-Biddle, K., Dutton, J.E., Eds.; Routledge: London, UK, 2012; pp. 131-153.

24. Stubbs, W. Characterising B Corps as a sustainable business model: An exploratory study of B Corps in Australia. J. Clean. Prod. 2017, 144, 299-312. [CrossRef]

25. Woodhouse, P. Beyond industrial agriculture? Some questions about farm size, productivity and sustainability. J. Agric. Chang. 2010, 10, 437-453. [CrossRef]

26. Holt, A.R.; Alix, A.; Thompson, A.; Maltby, L. Food production, ecosystem services and biodiversity: We can't have it all everywhere. Sci. Total Environ. 2016, 573, 1422-1429. [CrossRef] [PubMed]

27. Batáry, P.; Gallé, R.; Riesch, F.; Fischer, C.; Dormann, C.F.; Mußhoff, O.; Császár, P.; Fusaro, S.; Gayer, C.; Happe, A.K.; et al. The former Iron Curtain still drives biodiversity-profit trade-offs in German agriculture. Nat. Ecol. Evol. 2017, 1, 1279-1284. [CrossRef] [PubMed]

28. Landis, D.A. Designing agricultural landscapes for biodiversity-based ecosystem services. Basic Appl. Ecol. 2017, 18, 1-12. [CrossRef]

29. Baumgartner, R.J. Critical perspectives of sustainable development research and practice. J. Clean. Prod. 2011, 19, 783-786. [CrossRef]

30. Mace, G.M.; Reyers, B.; Alkemade, R.; Biggs, R.; Chapin, F.S., III; Cornell, S.E.; Díaz, S.; Jennings, S.; Leadley, P.; Mumby, P.J.; et al. Approaches to defining a planetary boundary for biodiversity. Glob. Environ. Chang. 2014, 28, 289-297. [CrossRef]

31. Barbier, E.B.; Burgess, J.C. Natural Resource Economics, Planetary Boundaries and Strong Sustainability. Sustainability 2017, 9, 1858. [CrossRef]

32. Hart, S.; Milstein, M. Global sustainability and the creative destruction of industries. MIT Sloan Manag. Rev. 1999, 41, 23-33.

33. Stubbs, W.; Cocklin, C. Conceptualizing a "sustainability business model". Organ. Environ. 2008, 21, $103-127$. [CrossRef]

34. Laasch, O. Beyond the purely commercial business model: Organizational value logics and the heterogeneity of sustainability business models. Long Range Plan. 2018, 51, 158-183. [CrossRef]

35. Bocken, N.M.; Short, S.W.; Rana, P.; Evans, S. A literature and practice review to develop sustainable business model archetypes. J. Clean. Prod. 2014, 65, 42-56. [CrossRef]

36. Rauter, R.; Jonker, J.; Baumgartner, R.J. Going one's own way: Drivers in developing business models for sustainability. J. Clean. Prod. 2017, 140, 144-154. [CrossRef]

37. Markman, G.D.; Russo, M.; Lumpkin, G.T.; Jennings, P.D.; Mair, J. Entrepreneurship as a Platform for Pursuing Multiple Goals: A Special Issue on Sustainability, Ethics, and Entrepreneurship. J. Manag. Stud. 2016, 53, 673-694. [CrossRef]

38. Schlange, L. Stakeholder identification in sustainability entrepreneurship: The role of managerial and organisational cognition. Greener Manag. Int. 2006, 55, 13-32. [CrossRef]

39. Costa, E.; Pesci, C. Social impact measurement: Why do stakeholders matter? Sustain. Account. Manag. Policy J. 2016, 7, 99-124. [CrossRef] 
40. DiMaggio, P. Interest and agency in institutional theory. In Institutional Patterns and Organizations; Zucker, L., Ed.; Ballinger: Cambridge, MA, UK, 1988; pp. 3-21.

41. Schaltegger, S.; Wagner, M. Sustainable entrepreneurship and sustainability innovation: Categories and interactions. Bus. Strategy Environ. 2011, 20, 222-237. [CrossRef]

42. Strauss, A.; Corbin, J. Basics of Qualitative Research: Procedures and Techniques for Developing Grounded Theory; SAGE: Thousand Oaks, CA, USA, 1998.

43. Alvesson, M.; Deetz, S. Doing Critical Management Research; Sage: London, UK, 2000.

44. Villarreal, O. Is it desirable, necessary and possible to perform research using case studies? Cuad. Gest. 2016, 17, 147-172. [CrossRef]

45. Yin, R.K. Case Study Research: Design and Methods; Sage Publications: London, UK, 1994.

46. Meyer, C.B. A case in case study methodology. Field Method 2001, 13, 329-352. [CrossRef]

47. Alberti, F.G.; Varon, M.A. Can profit and sustainability goals co-exist? New business models for hybrid firms. J. Bus. Strategy 2017, 38, 3-13. [CrossRef]

48. Compés-López, R.; Asensio-Calatayud, I. Economía del bien común y minifundismo en el sector agroalimentario: El caso del Celler La Muntanya (Alicante) y la marca Microviña. Rev. Esp. Estud. Agrosoc. Pesq. 2014, 237, 181-209.

49. Ferrás, C.; Macía, X.C.; García, M.Y.; Armas, F.X. El minifundio sostenible como un nuevo escenario para la economía gallega. Revista Galega de Economia 2004, 13, 1-25.

50. López-Navarro, M.Á. Caracterización de los consorcios de exportación en el sector agroalimentario español. Rev. Esp. Estud. Agrosoc. Pesq. 2001, 193, 143-168.

51. Colombo, S.; Perujo-Villanueva, M. Analysis of the spatial relationship between small olive farms to increase their competitiveness through cooperation. Land Use Policy 2017, 63, 226-235. [CrossRef]

52. Dias, C.; Franco, M. Cooperation in tradition or tradition in cooperation? Networks of agricultural entrepreneurs. Land Use Policy 2018, 71, 36-48. [CrossRef]

53. Felber, C. Change Everything. Creating an Economy for the Common Good; Zed Books Ltd.: London, UK, 2015.

54. Celler la Muntanya. Official website. Available online: http://cellerlamuntanya.com (accessed on 25 May 2018).

55. Vinetur (La Revista Digital del Vino). Nace Quàntic, el Vino Cuántico. 2015. Available online: https: / / www.vinetur.com/2015070920193/nace-quantic-el-vino-cuantico.html (accessed on 18 May 2018).

56. Baker, T. Microvinyas: Ethical Vineyards Producing Wine for the Common Good. The Guardian. 21 January 2014. Available online: https:/ / www.theguardian.com/lifeandstyle/wordofmouth/2014/jan/ 21/microvinyas-ethical-vineyards-wine-investor-small-plot (accessed on 18 May 2018).

57. Celler la Muntanya. Vi i Amics-Micro-Documental Celler la Muntanya (video). Available online: https: / /vimeo.com/61827347 (accessed on 18 May 2018).

58. Vinetur (La Revista Digital del Vino). Microviña Recupera la Casa Alonso de Muro, un Símbolo del Esplendor Vitivinícola de El Comtat. 2014. Available online: https:/ / www.vinetur.com/2014101017006/microvinarecupera-la-casa-alonso-de-muro-un-simbolo-del-esplendor-vitivinicola-de-el-comtat.html (accessed on 18 May 2018).

59. Vinetur (La Revista Digital del Vino). Arranca el ‘I Curso Microviña, una Herramienta Para el Desarrrollo Rural' de la Universidad de Alicante. 2013. Available online: https://www.vinetur.com/2013110813847/ arranca-el-i-curso-microvina-una-herramienta-para-el-desarrrollo-rural-de-la-universidad-de-alicante. html (accessed on 18 May 2018).

60. Ehrenfeld, J.E. Sustainability by Design; Yale University Press: New Haven, CT, USA, 2008.

61. Tencati, A.; Zsolnai, L. Collaborative enterprise and sustainability: The case of slow food. J. Bus. Ethics 2012, 110, 345-354. [CrossRef]

62. Starik, M. Should trees have managerial standing? Toward stakeholder status for non-human nature. J. Bus. Ethics 1995, 14, 207-217. [CrossRef]

63. Driscoll, C.; Starik, M. The primordial stakeholder: Advancing the conceptual consideration of stakeholder status for the natural environment. J. Bus. Ethics 2004, 49, 55-73. [CrossRef]

64. Haigh, N.; Griffiths, A. The natural environment as a primary stakeholder: The case of climate change. Bus. Strategy Environ. 2009, 18, 347-359. [CrossRef]

65. Maak, T. Responsible Leadership, Stakeholder Engagement, and the Emergence of Social Capital. J. Bus. Ethics 2007, 74, 329-343. [CrossRef] 
66. Klapper, R.G.; Upham, P. The impact of micro-firm everyday practices on sustainable development in local communities. In Handbook of Entrepreneurship and Sustainable Development Research; Kyrö, P., Ed.; Edward Elgar Publishing Limited: Cheltenham, Northampton, UK, 2015; pp. 275-299.

67. Kurucz, E.C.; Colbert, B.A.; Luedeke-Freund, F.; Upward, A.; Willard, B. Relational leadership for strategic sustainability: Practices and capabilities to advance the design and assessment of sustainable business models. J. Clean. Prod. 2017, 140, 189-204. [CrossRef]

68. Kraus, S.; Burtscher, J.; Vallaster, C.; Angerer, M. Sustainable Entrepreneurship Orientation: A Reflection on Status-Quo Research on Factors Facilitating Responsible Managerial Practices. Sustainability 2018, 10, 444. [CrossRef]

69. Boyd, B.; Henning, N.; Reyna, E.; Wang, D.; Welch, M.; Hoffman, A.J. Hybrid Organizations: New Business Models for Environmental Leadership; Routledge: London, UK, 2017.

70. Darnall, N.; Henriques, I.; Sadorsky, P. Adopting proactive environmental strategy: The influence of stakeholders and firm size. J. Manag. Stud. 2010, 47, 1072-1094. [CrossRef]

71. Shevchenko, A.; Lévesque, M.; Pagell, M. Why firms delay reaching true sustainability. J. Manag. Stud. 2016, 53, 911-935. [CrossRef]

(C) 2018 by the authors. Licensee MDPI, Basel, Switzerland. This article is an open access article distributed under the terms and conditions of the Creative Commons Attribution (CC BY) license (http://creativecommons.org/licenses/by/4.0/). 